\title{
COVID-19 Outbreak: An Analysis of Malaysian Household Income Class During Movement Control Order (MCO)
}

\author{
MOHD KHAIRI ISMAIL ${ }^{1 *}$, VIKNISWARI VIJA KUMARAN ${ }^{2}$, SITI NURUL MUNAWWARAH ${ }^{3}$, \\ MUHAMAD ZAHID MUHAMAD ${ }^{4}$, SYAMSULANG SARIFUDDIN ${ }^{5}$ \\ ${ }^{1}$ Faculty of Business \& Management, UNIVERSITI TEKNOLOGI MARA (UITM), MALAYSIA. \\ E-mail: khairiismail@uitm.edu.my \\ ${ }^{2}$ Faculty of Business and Finance, UNIVERSITI TUNKU ABDUL RAHMAN (UTAR), MALAYSIA. \\ E-mail: vikniswarivk@utar.edu.my \\ ${ }^{3}$ Faculty of Business Management and Professional Studies, MANAGEMENT \& SCIENCE UNIVERSITY, MALAYSIA. \\ E-mail: sitinurul_munawwarah@msu.edu.my \\ ${ }^{4}$ Faculty of Plantation and Agrotechnology, UNIVERSITI TEKNOLOGI MARA, MALAYSIA. \\ E-mail: zahid5264@uitm.edu.my \\ ${ }^{5}$ ELM Business School, HELP UNIVERSITY, MALAYSIA. E-mail: ssyamsulang@help.edu.my
}

\begin{abstract}
The outbreak of COVID-19 has caused the Malaysian Government to take several steps towards the implementation of Movement Control Order (MCO). According to Bank Negara Malaysia, the implementation of MCO affects the national income with the estimated economic growth of Malaysia in 2020 which is expected to be around $-2 \%$ to $0.5 \%$. The effects of MCO due to COVID-19 not only affects the macro level but at micro level as well, especially those group of households. The group of households were expected to face high economic risk and directly affect their consumption patterns during the implementation of MCO. This study will analyze the pattern of households' consumption in Malaysia based on different income groups which is B40 and M40 during the implementation of MCO due to the spread of COVID-19 pandemic. The findings show that the groups of household experienced changes in daily consumption patterns after the implementation of MCO. In addition, due to insufficient savings, this has caused the households stay anxious of their consumption especially if the $\mathrm{MCO}$ is further extended for longer period.
\end{abstract}

Keywords: Covid-19, Movement Control Order (MCO), B40 \& M40 Household Consumption

JEL Classification: D12; D14; G51 


\section{Introduction}

The pandemic of COVID-19 has developed into a health, socio-economic and of unprecedented size and effect, and overall humanitarian crises. The scenario in the fact that the government only came to control is compounded by Malaysia At the beginning of March 2020, Malaysia has facing a strong debt crisis and financial with dropping in oil prices and knock-on impact on commerce and tourism shut down at global level. The Movement Control Order (MCO) came into force on March 18, 2020. Despite the oppression of the people, especially those involved in small and medium businesses, the government had to extend the MCO period to avoid the risk of COVID-19 being infected from sporadic or unconscious civil cases they are infected with the virus. The government is also desperate to extend the MCO to ensure that the lives of the people are not threatened by the COVID-19 pandemic. In fact, the extension of MCO is in line with the advice of the World Health Organization (WHO) which urges all not to withdraw MCO in their respective countries until the threat of the COVID-19 pandemic can be completely curbed.

The implementation of MCO has affected household consumption across groups. According to (Department of Statistics Malaysia Official Portal, n.d.), the average consumer expenditure, excluding financial expenditure, decreased by RM1,923 (48 per cent) to RM2,110 under MCO. Among the main categories that recorded the biggest declines were clothing and footwear (95 percent); transportation (89 percent); restaurants and hotels (86 percent); and home decoration, hardware and maintenance (72 percent). In addition, among other categories that were also affected were recreational and cultural services (71 percent); alcoholic beverages and tobacco (65 percent); and housing, water, electricity, gas and other fuels (58 per cent). However, at the same time spending on food and nonalcoholic beverages increased by 27 percent due to the need for more raw materials for the purpose of eating at home. Following restrictions were placed on eateries and social incarceration practices during $\mathrm{MCO}$, the food and beverage dominated the average household expenditure by 44 per cent compared to 18 per cent before MCO.

The implementation of MCO has affected household consumption across groups. According to (Department of Statistics Malaysia Official Portal no date), the average consumer expenditure, excluding financial expenditure, decreased by RM1,923 (48 per cent) to RM2,110 under MCO. Among the main categories that recorded the biggest declines were clothing and footwear (95 percent); transportation ( 89 percent); restaurants and hotels ( 86 percent); and home decoration, hardware and maintenance (72 percent). In addition, among other categories that were also affected were recreational and cultural services (71 percent); alcoholic beverages and tobacco (65 percent); and housing, water, electricity, gas and other fuels (58 per cent). However, at the same time spending on food and non-alcoholic beverages increased by 27 percent due to the need for more raw materials for the purpose of eating at home. Following restrictions were placed on eateries and social incarceration practices during $\mathrm{MCO}$, the food and beverage dominated the average household expenditure by 44 per cent compared to 18 per cent before MCO.

The effects of MCO because of COVID-19 not only affect the macro level but at micro level as well, especially those groups of households. The group of households who expected to face high economic risk and directly affect their consumption patterns during the implementation of MCO. Therefore, this study aims to analyze the pattern of households' consumption in Malaysia based on different income groups which is the bottom $40 \%$ of income earners (B40) and middle $40 \%$ of income (M40) during the implementation of MCO due to the spread of COVID-19 pandemic.

\section{Literature Review}

\subsection{Financial Well Being (FWB) in Malaysia Context}

The pandemic of COVID-19 has developed into a health, socio-economic and of unprecedented size and effect, and overall humanitarian crises. The scenario in the fact that the government only came to control is compounded by Malaysia At the beginning of March 2020, Malaysia has facing a strong debt 
crisis and financial with dropping in oil prices and knock-on impact on commerce and tourism shut down at global level. The Movement Control Order (MCO) came into force on March 18, 2020. Despite the oppression of the people, especially those involved in small and medium businesses, the government had to extend the MCO period to avoid the risk of COVID-19 being infected from sporadic or unconscious civil cases they are infected with the virus. The government is also desperate to extend the MCO to ensure that the lives of the people are not threatened by the COVID-19 pandemic. In fact, the extension of MCO is in line with the advice of the World Health Organization (WHO) which urges all not to withdraw MCO in their respective countries until the threat of the COVID-19 pandemic can be completely curbed.

In Malaysia, research on the FWB have echoed the contradictions in measurements as well as in foreign contexts. The number of measurement items of the subjective FWB construct, varying from four to twelve items, indicates variations (Sabri, Zakaria 2015; Mokhtar et al. 2015; Mokhtar, Husniyah 2017). Apart from that, few have used FWB's quantitative metrics such as saving and debt-payment ratios (e.g. (Zaimah et al. 2013). In addition, the work tends to be very selective since most of the studies were based on a relatively small sample size and concentrated on particular segments of society, such as public sector workers, elderly people or college students (Zaimah et al. 2013; Mokhtar et al. 2015; Mokhtar, Husniyah 2017; Yin-Fah et al. 2010; Sabri, Falahati 2012). This has been supported by Brüggen et al., (2017) in view of the above problems in the concept and calculation of FWB, that the subjective approach might be a more suitable measure because only a person can determine the degree of his/her own financial well-being. Consequently, one's level of revenue will not affect financial well-being. There are so many other heterogeneous variables, such as family size, expenses, debt, and incidents of stress.

In Malaysia, the issue of cost of living becomes a popular issue in recent years. This is evidenced by the concern of the Malaysian government by outlining some special steps inside national budget each year. For example, in year 2017, based on Ministry of Finance report, via national budget 2018, the government emphasizes the improvements of the lives of the people through various initiatives. Due to the volatile gasoline prices increase the cost of transportation of the people, the government has approve and expedite several projects large public transport such as construction MRT3 worth 50 billion, East Coast Rail Link (ECRL) worth RM144 billion and KL-SG High Speed Rail (HSR) worth RM43 billion. Through this mega project the government hopes this public transport system is affordable and replaces consumption private transportation as well as reducing costs transportation per household by 30 percent up to 50 percent (Ministry of Finance Malaysia 2017). Meanwhile according to the Bank Negara Malaysia (2017), the estimated salary for an adult individual bachelors standard living in Kuala Lumpur is around RM2,700 per month which indirectly bring signal that high pay needed to live in big cities in Malaysia. This shows the cost of the livelihood of the people in the city has increased every day. The rising cost of living is getting higher when the cost of home ownership began to increase since 2009.

\subsection{Consumption of $\mathrm{M} 40$ and $B 40$ Group}

Consumption is the state of spending of individuals for buying goods for a given period. According to Mankiw (2000), consumption is the situation where the household purchased product or services, consumption consists of non-durable products that constitute short-term items, such as food and clothes, and durable goods that constitute a long-lived product, such as vehicles, televisions, mobile gadgets and mobile phones. Household expenditure is the value of household spending to purchase several necessities each year. Human behaviours and any changes in habits of consumption have a powerful impact on the environment. According to Zainudin, N., Siwar, C., Choy, E.A. \& Chamhuri (2016), decisions on household expenditure are essential in preserving the global environment.

The money earned by the family (households) will be used to purchase food, finance transportation utilities, pay the tuition fees of children, pay house rental and purchase motor vehicles. To satisfy the requirement, these items are purchased by the household, and the spending is called as consumption (Zainudin, N., Siwar, C., Choy, E.A. \& Chamhuri 2016). However, not all domestic purchases are grouped 
into consumption. When the household are buying a new house, it will be categorized under investment. Then some of their expenditures, such as paying premiums and sending money to parents (or to studying children) are not classified into consumption because they are the investment generated in the economy over the product or service.

Schulte \& Heindl (2017) has studied the elasticity of demand electricity for residential areas in Germany. This study concludes that household from different income groups look at spending for electricity as an expenses on different type of goods (luxury goods, normal or subordinate) based on elasticity of demand. Binet (2013) has studied the elasticity of demand among French population against public goods and found the elasticity of demand for public goods is low (less than 0 ) when there is an increase income, which signifies public goods is subordinate goods. Lopez-Calva et al. (2012) defined the population in two group; which is middle class for group M40 and lower class set for group B40. The middle classes have been described as the segment that is not currently experiencing poverty, but is vulnerable to a deprived economic condition that prevents basic needs from being met and lacks economic assets to ensure maximum security against poverty, hence their vulnerability. Thus, this study contributes to literature based on two income groups namely M40 and B40 in Malaysia. Though past studies have explored at some aspects of the cost of living and income, yet only few studies explored the effects of COVID-19 on living standards and how living standards cause the subsistence costs of living. Although Schulte \& Heindl (2017) who analysed the difference household income group contributes to patterns of electricity expenditure, yet expenditure electricity is a small component of expenditure household, and not quite significant in giving implications for the cost of living. Moreover, Song (2011) has also focused in rural populations, not on group-based income. Therefore, this study will contribute to body of knowledge by analyzing the consumption pattern during and after pandemic.

\section{Methodology}

This study is based on quantitative research. Data was collected via online survey. Distribution of online survey was conducted between 1 April 2020 to 30 May 2020 for the whole states of Malaysia. Prior to the distribution of the survey, the population determination is necessary to ensure sampling can be done. For this study, population under B40 (Bottom 40\%) as those with household income of less than RM4,360 per month and M40 (Middle 40\%) with household income between RM4,360 and RM9,619 that registered in the information system of the Department of Statistics Malaysia have been chosen. According to Krejcie \& Morgan (1970), if the total population exceeds 100,000 people, researchers need a total of 384 samples for analysis and it suffices to describe the characteristics of the population. In this study, M40 the population of B40 households in Malaysia is 2.78 million people and this means that this study needs at least 384 respondents. However, this study used 505 respondents from B40 group and 257 respondents from M40 as the study sample.

Descriptive analysis and multiple regression analysis have been employed. The descriptive analysis was carried out using tables and percentages to describe the profile of respondents, financial analysis and consumption analysis of respondents, both for B40 and M40. Multiple regression analysis is conducted to analyze the relationship between income (total salary of respondents) and predictor variables are the dependent components of respondents. Multiple regression analysis is a statistical technique used to analyze the relationship between a criterion variable (dependent variable) and a set of predictor variables (independent variables). These predictor variables are factors that affect the criterion variable (dependent variable). This study uses the Regression of Multiple Statistics, which is to include predictive variables (independent variables) into the multiple regression equations not based on the importance of predictor variables to the criteria (dependent variables) based on the theory and information of previous studies, instead it is based on statistical criteria (Piaw 2009). This means that the predictor variable with the strongest correlation with the criterion variable (dependent variable), will be included in the multiple regression and followed by the second strong correlation variable, and so on. In this study the criterion variables are represented by the total salary of the respondent and the predictor variables are the dependent components of the respondent. 
In this study, multiple regression involves predictive variables or independent variables (X) consisting of dependent components. In this study, various regression involves predictive variables or independent variables $(X)$ namely housing loans $\left(X_{1}\right)$, personal loans $\left(X_{2}\right)$, personal vehicle loans ( $\left.X_{3}\right)$, credit card payments $\left(X_{4}\right)$, business loans $\left(X_{5}\right)$, education loans $\left(X_{6}\right)$, individual debt $\left(X_{7}\right)$, and house rental $\left(X_{8}\right)$. Criterion variable / dependent variable $\left(\mu^{\mu}\right)$ which is the income of B40 respondents. By using multiple regression, there are 8 factors or components of dependents (predictor variables) that affect the income of the dependent variable / criterion variable $(\boldsymbol{\mu})$ which is the total salary of the respondent.

$$
\mu=\beta_{0}+b X_{1}+b X_{2}+b X_{3}+b X_{4}+b X_{5}+b X_{6}+b X_{7}+b X_{8}+\mu
$$

Where:

$\boldsymbol{\mu}=$ dependent variable / criterion / income variable

$\beta=$ regression coefficient for each predictor variable / independent variable / component Individual dependents

\section{Results and findings}

\subsection{Descriptive Analysis}

Table 1.1 shows the profiles of the respondents. This section discusses on socio-demographic characteristics for two groups of income: B40 and M40 respectively. Collected information involved participants' age, state, type of area, sex, education level, working sector, salary type, and monthly salary. All respondents are households living in Malaysia during the implementation period of MCO. Selangor and Penang recorded the highest percentage of respondents, which is 25 percent and 15.3 percent respectively. The Federal Territory of Putrajaya shows the lowest percentage of 0.8 percent, and this percentage corresponds to the small number of B40 in this area. Details by area show that 65.3 percent of respondents live in urban areas, and the rest are in rural areas.

\subsubsection{B40 socio-demographic information}

In terms of demographics and geographical area, the study involved a total of 505 respondents under B40. Based on the data, most of the respondents, comprise 55.2 percent, are males and $44.8 \%$ percent are females. Most of the respondents come from Selangor (27.8\%) and Pulau Pinang (14.2\%). When asked to classify their locality if they are coming from urban or rural area, $65.3 \%$ comes from urban area and remaining are from rural area. Nearly half of the participants $(41.7 \%)$ are $31-40$ years old.

The responses for respondent's education included Doctor of Philosophy (PhD), Master, Bachelor Degree, Diploma, STPM/Certificate, SPM/MCE, PMR/SRP, UPSR and no formal education. About $62.1 \%$ of survey participants had higher education, and $1.6 \%$ with no formal education. From this $\mathrm{B} 40$ group, almost half of the respondents work in the private sector (47.4\%). $66.9 \%$ of the respondents received their salary on monthly basis. In terms of monthly salary, they are grouped into 4 categories, and most of the respondents have salary ranging between RM981 to RM2614 and between RM2615 to RM4360 recording $41.7 \%$ and $41.3 \%$ respectively.

\subsubsection{M40 socio-demographic information}

From the total of 762 respondents 257 of them falls under the M40 group. In terms of gender, 51.6 percent, are males and 48.4 percent are females. Majority come from Selangor (33.3\%) and Pulau Pinang (12\%). Survey participants are mostly from urban areas (70.2 per cent). 35.7 per cent of the respondents are between 31-40 years old. The responses for respondent's education exhibited 34.9 per cent of respondents have bachelor degree. Approximately $91.5 \%$ of survey participants had higher 
education (Diploma and above), and $0.4 \%$ with no formal education. Almost half of the M40 respondents work in the government sector (46.5\%). $75.2 \%$ of the respondents received their salary on monthly basis. In terms of monthly salary, they all belong to between RM4361 dan RM9619 category.

Table 1.1 Respondents Demographic Data

\begin{tabular}{|c|c|c|c|c|c|c|c|}
\hline Household Income Class & Total & B40 & M40 & \multirow{2}{*}{$\begin{array}{l}\text { Household Income Class } \\
\text { Race }\end{array}$} & Total & B40 & M40 \\
\hline Gender & \multicolumn{3}{|l|}{$\%$} & & \multicolumn{3}{|l|}{$\%$} \\
\hline Male & 53.9 & 55.2 & 51.6 & Malay & 68.2 & 72.8 & 59.3 \\
\hline Female & 46.1 & 44.8 & 48.4 & Chinese & 14.7 & 9.5 & 24.8 \\
\hline State & & & & Indian & 12.3 & 11.1 & 14.7 \\
\hline Perlis & 1.4 & 1.4 & 1.6 & Others & 4.7 & 6.5 & 1.2 \\
\hline Kedah & 7.7 & 8.9 & 5.4 & Education Level & & & \\
\hline Pulau Pinang & 14.2 & 15.3 & 12.0 & Doctor of Philosophy (PhD) & 6.4 & 3.8 & 11.6 \\
\hline Perak & 8.1 & 8.3 & 7.8 & Master & 13.8 & 10.9 & 19.4 \\
\hline Selangor & 27.8 & 25.0 & 33.3 & Bachelor Degree & 29.7 & 27.0 & 34.9 \\
\hline Johor & 9.2 & 7.9 & 11.6 & Diploma & 22.2 & 20.4 & 25.6 \\
\hline Negeri Sembilan & 2.8 & 1.8 & 4.7 & STPM/Certificate & 4.9 & 6.5 & 1.6 \\
\hline Melaka & 2.1 & 1.4 & 3.5 & SPM/MCE & 18.1 & 24.4 & 5.8 \\
\hline Pahang & 3.1 & 3.2 & 3.1 & PMR/SRP & 3.0 & 4.4 & 0.4 \\
\hline Terengganu & 3.1 & 2.8 & 3.9 & UPSR & 0.8 & 1.0 & 0.4 \\
\hline Kelantan & 5.5 & 6.3 & 3.9 & No education & 1.2 & 1.6 & 0.4 \\
\hline Sabah & 3.7 & 5.4 & 0.4 & Sectors & & & \\
\hline Sarawak & 2.4 & 2.8 & 1.6 & Government & 32.0 & 24.6 & 46.5 \\
\hline W.P. Labuan & 0.3 & 4.0 & 1.9 & Private & 46.3 & 47.4 & 44.2 \\
\hline W.P. Putrajaya & 1.2 & 0.8 & 1.9 & Self- employed & 21.7 & 28.0 & 9.3 \\
\hline W.P. Kuala Lumpur & 7.3 & 8.3 & 5.4 & Salary & & & \\
\hline Area & & & & Hours/Weekly/Daily & 13.3 & 13.7 & 12.4 \\
\hline Urban & 66.9 & 65.3 & 70.2 & Monthly Basis & 69.7 & 66.9 & 75.2 \\
\hline Rural & 33.1 & 34.7 & 29.8 & $\begin{array}{l}\text { Based on Request/task } \\
\text { performed }\end{array}$ & 17.1 & 19.4 & 12.4 \\
\hline Age & & & & Monthly Salary & & & \\
\hline $18-25$ years old & 15.7 & 11.1 & 24.8 & Less than RM580 & 5.0 & 7.5 & 0 \\
\hline $26-30$ years old & 14.2 & 18.5 & 5.8 & Between RM580 - RM980 & 6.3 & 9.5 & 0 \\
\hline $31-40$ years old & 39.5 & 41.7 & 35.3 & Between RM981 - RM2614 & 27.6 & 41.7 & 0 \\
\hline 41-60 years old & 28.7 & 26.2 & 33.7 & Between RM2615 - RM4360 & 27.3 & 41.3 & 0 \\
\hline Above 61 years old & 14.2 & 2.6 & 0.4 & $\begin{array}{l}\text { Between RM4361 dan } \\
\text { RM9619 }\end{array}$ & 33.9 & 0 & 100 \\
\hline
\end{tabular}

In general, analysis based on social composition shows that,-Malays are showing the highest percentage, followed by Indian and Chinese. There are respondents who are from other races that participated in this survey, which consist of 4.7 percent. The percentages by race in this study are consistent with Malaysia Statistics, which shows the composition of B40 and M40 by the number of Malay, Indian and Chinese. In terms of the highest level of education, there are three levels of 
education that show high percentage which is more than 20 percent, namely bachelor's degree, diploma, and Sijil Pelajaran Malaysia (SPM / MCE) with a total percentage of 71.4 percent. This situation shows that most of the respondents have completed at least their secondary studies and belong to group B40.

Besides, data shows that 46.3 percent of respondents are working in private sector and only 32 percent in the government sector. Moreover, there are 21.7 percent self-employed respondents. Thus, involvement in the employment sector will determine the form of salary earnings by the respondents. Based on Table 1.1, there are three forms of salary earnings of respondents which are based on hours / daily / weekly, based on monthly and finally according to the request / task performed. Of the three categories, most respondents (69.7 percent) are earning monthly salary.

\subsection{Comparison Between M40 \& B40 (Financial Analysis)}

Financial analysis involves the impact of the implementation of MCO in terms of financial and savings sources, availability of savings, financial capability to recover, planning to restore financial resources, and action taken in the event of emergencies such as MCO in the future (Ismail, M. K., Kumaran, V. V., \& Munawwarah 2021). The Table 1.2 shows the effect of MCO implementation on the financial source and savings of respondents.

The majority of respondents stated that the implementation of MCO affects their financial and savings sources. There were 31.3 percent who stated that the implementation of MCO did not affect their work and salary. Whereas for group M40 around 44.6 percent responded that MCO does not affect their work and salary. Besides, respondents experienced a loss of the basic salary percentage and lost source of income with the percentages were 27 percent and 19.6 percent respectively. Whereas for M40 the percentage are 12.4 percent and 7.4 percent respectively. Respondents stated that their salaries were cut around 10 to $20 \%$ because employers from private companies could not afford to pay full salaries because the activities of the company or organization could not be performed during MCO. For the loss of sources of income, respondents are small businesses that are unable to carry out business activities during the implementation of $\mathrm{MCO}$ and affect their income and consumption during MCO (Ismail, M. K., Kumaran, V. V., \& Munawwarah 2021).

Table 1.2 Impact of MCO on financial and savings sources

\begin{tabular}{|l|c|c|c|}
\hline \multirow{2}{*}{ Financial and Savings Sources } & Total & B40 & M40 \\
\cline { 2 - 4 } & \multicolumn{3}{|c|}{$\%$} \\
\hline Does not affect work and salary & 35.8 & 31.3 & 44.6 \\
\hline Downstructure & 3.0 & 3.4 & 2.3 \\
\hline Loss of half salary & 8.5 & 8.9 & 7.8 \\
\hline Leave without pay & 9.1 & 9.7 & 7.8 \\
\hline Lost source of income (unable to trade) & 15.5 & 19.6 & 7.4 \\
\hline Loss of some percentage of basic salary & 12.5 & 27 & 12.4 \\
\hline
\end{tabular}

Analysis of respondents' savings for spending shows that 45 percent of respondents have savings of less than 1 month of spending. In addition, a high percentage also indicates a situation where 38.5 percent of respondents have savings of 1 to 3 months only. Whereas for M40, most of the respondents indicates savings is for 1 to 3 months only. This situation shows that majority of the respondents have savings for less than six months. If the MCO is implemented for more than six months, it will affect the respondents and they need to get incentives from the government (Wang et al. 2020).

For respondents who have savings for spending more than six months, the percentage is low at only 5.6 percent. The respondents' savings analysis is not an abnormal situation because the characteristics of the B40 group itself that involved in low-income economic activities and this affects their consumption and savings (Ismail et al. 2019; Zuriati Amani Ab Rani et al. 2019). For M40, majority of 
them have saving for spending between 3 to up to 6 months compared to B40. This is because of their income that is not much affected compared to B40 group.

Table 1.3 Savings for spending in the next six (6) months

\begin{tabular}{|l|c|c|c|}
\hline \multirow{2}{*}{ Savings for Spending } & Total & \multicolumn{3}{|c|}{ B40 } & M40 \\
\cline { 2 - 5 } & \multicolumn{3}{|c|}{$\%$} \\
\hline Less than 1 month of spending & 39.5 & 45.8 & 27.1 \\
\hline 1 to 3 months of spending & 39.5 & 38.5 & 41.5 \\
\hline 3 to 6 months of spending & 12.5 & 10.1 & 17.1 \\
\hline More than 6 months of spending & 8.5 & 5.6 & 14.3 \\
\hline
\end{tabular}

Moving to the analysis of the savings owned by the respondents, it shows that they are used for the purchase of basic and main things, namely buying food supplies, paying utility bills, medicines, spending petrol. For spending on things like investing and entertainment spending shows a low percentage. This situation shows that the B40 households are planning to use their savings for basic daily needs compared to M40. Apart from that, giving donations / donations / alms shows a high percentage of 31.9 for B40 and 33.3 percent for B40, which means that the respondents for both groups are very focused on welfare matters to help the community.

Table 1.4 Savings are sufficient for purchases and payments

\begin{tabular}{|l|c|c|c|}
\hline \multirow{2}{*}{ Purchases and Payments } & Total & \multicolumn{2}{|c|}{ B40 } \\
\cline { 2 - 4 } & \multicolumn{3}{|c|}{ M40 } \\
\hline Buying food supplies & 94.6 & 96.2 & 91.5 \\
\hline Buying a supply of medicine & 63.0 & 61.9 & 65.1 \\
\hline Pay off debt & 0.4 & 0.6 & 0 \\
\hline Make savings & 22.2 & 17.3 & 31.8 \\
\hline Make an investment & 5.4 & 3.6 & 8.9 \\
\hline Entertainment spending & 5.2 & 3.6 & 8.5 \\
\hline Buying / paying insurance & 23.1 & 17.3 & 34.5 \\
\hline Pay utility bills & 65.9 & 66.1 & 65.5 \\
\hline Pay medical expenses & 16.5 & 14.1 & 21.3 \\
\hline Gasoline spending & 48.3 & 49.4 & 46.1 \\
\hline Online purchase & 27.2 & 25.2 & 31.0 \\
\hline Giving donations / donations / alms & 32.4 & 31.9 & 33.3 \\
\hline
\end{tabular}

Respondents provided their feedback on the issue of their financial ability to recover due to COVID19 and implementation of MCO. Majority of respondents stated that their finances recovered within 1 to 6 months. There are 21.4 percent for $\mathrm{B} 40$ and 20.2 percent for $\mathrm{M} 40$ indicated that they need more than 6 months to recover financially. However, the situation is quite different for 5.4 percent of respondents and slightly higher for 6.6 percent from M40 group, who stated that their finances could not recover totally. Based on the analysis it clearly shows that 1 to 6 months or more is important for the respondents for their finances. During this period, a support or incentive should be provided by certain parties to help the respondents. Incentives can include deferment of monthly payments (moratorium), tax exemption, financial and non-financial assistance (Baker et al. 2020). 
Table 1.5 Financial ability to recover

\begin{tabular}{|c|c|c|c|}
\hline \multirow{2}{*}{ Financial ability } & Total & B40 & M40 \\
\hline & \multicolumn{3}{|c|}{$\%$} \\
\hline Finance is not affected & 23.0 & 20.8 & 27.1 \\
\hline Unable to & 5.8 & 5.4 & 6.6 \\
\hline 1 to 3 months & 27.3 & 27.2 & 27.5 \\
\hline 3 to 6 months & 23.0 & 25.2 & 18.6 \\
\hline More than 6 months & 21.0 & 21.4 & 20.2 \\
\hline
\end{tabular}

Planning to return financial resources / income after $\mathrm{MCO}$ is important for respondents who belong to the B40 group to continue living (Baker et al. 2020). In percentage, 72.4 percent from B40 and 67.8 from M40 responded to work as usual after the MCO ended. There are 25.2 percent from B40 and 21.3 percent of respondents from M40 that planning to supplement their source of income to get on with life. There are respondents who need help from families, government, NGOs, and make loans, however the percentage is small.

Table 1.6 Planning to return financial resources / income after MCO

\begin{tabular}{|c|c|c|c|}
\hline \multirow{2}{*}{ Planning } & Total & B40 & M40 \\
\hline & \multicolumn{3}{|c|}{$\%$} \\
\hline Work as usual & 70.9 & 72.4 & 67.8 \\
\hline Increase the source of income & 52.1 & 56.7 & 43.0 \\
\hline Ask for help from family, government, NGOs & 13.4 & 13.3 & 13.2 \\
\hline Make a loan (family, friends, bank) & 10.6 & 11.9 & 8.1 \\
\hline No planning & 15.9 & 13.9 & 19.8 \\
\hline
\end{tabular}

Respondents also stated some actions that will be taken if they face some emergencies such as $\mathrm{MCO}$ in the future. Majority of respondents, which is around 85.1 percent from B40 and 83.3 percent from M40 stated that they will make savings for emergency use in future. There are also respondents planning to diversify economic resources or income, which is around 52.2 percent from B40 and 43.0 percent from M40. Besides, around 36.7 percent from B40 and 34.1 percent from M40 indicated that all the spending will be according to their priority. This situation shows that the implementation of $\mathrm{MCO}$, respondents are more likely to focus on aspects of savings, income and expenditure management.

Table 1.7 Action taken if in the event of an emergency such as MCO in the future

\begin{tabular}{|l|c|c|c|}
\hline \multirow{2}{*}{ Action taken } & Total & B40 & M40 \\
\cline { 2 - 4 } & \multicolumn{3}{|c|}{$\%$} \\
\hline Make money savings & 84.5 & 85.1 & 83.3 \\
\hline Diversifying economic resources / income & 49.1 & 52.2 & 43.0 \\
\hline Spending by priority & 35.8 & 36.7 & 34.1 \\
\hline Addition of assets & 2.2 & 2.0 & 2.7 \\
\hline Following training that can help increase income & 2.6 & 2.0 & 3.9 \\
\hline
\end{tabular}

\subsection{Comparison Between M40 \& B40 (Consumption Analysis)}

The respondents' monthly expenses depend on loan repayments, individual debt payments and house rent (Cohen 2020). There are 8.3 percent of respondents stated that they are not dependent. In terms of loan liability, vehicle loans showed the highest percentage compared to other loans of 43.7 percent. Whereas from M40 group of respondents, personal loans show the highest level of percentage. Apart from that housing loans also showed a high percentage of 38.3 percent for B40 and 
48.4 percent for M40 respectively. Another interesting distribution was in terms of credit card loans which shows that B40 has been carrying of this burden compared to M40. This is because credit card allows them to make purchases and pay later compared to others. In that sense, it's like a short-term loan. Business loans are the lowest percentage because a minority of respondents are self-employed and make loans for their business.

Table 1.8 Monthly spending

\begin{tabular}{|l|c|c|c|l|c|c|c|}
\hline \multirow{2}{*}{ Liabilities } & T & B40 & M40 & \multirow{2}{*}{ Liabilities } & Total & B40 & M40 \\
\cline { 2 - 8 } & \multicolumn{3}{|c|}{$\%$} & \multicolumn{3}{|c|}{$\%$} \\
\hline Housing loan & 38.2 & 28.8 & 56.6 & Business loans & 2.5 & 3.4 & 0.8 \\
\hline Personal loan & 41.7 & 38.3 & 48.4 & Study loan & 15.5 & 18.3 & 10.1 \\
\hline Vehicle loans & 39.4 & 43.7 & 31.0 & Individual debt & 10.5 & 13.7 & 4.3 \\
\hline Credit card loans & 8.5 & 8.9 & 7.8 & House Rental & 8.9 & 10.7 & 5.4 \\
\hline
\end{tabular}

The table shows the analysis of respondents' consumption and expenditure involving food supply resistance and purchase frequency. Analysis of food supply resistance showed that 43.8 per cent from B40 respondents and 38.8 percent from M40 respectively had food supply resistance during MCO for 1 to 2 weeks. This situation the respondent is only able to have storage stock for daily use not exceeding 2 weeks only. In addition, there were 19.8 per cent from B40 and 23.3 percent from M40 that stating they had food supply resistance of less than a week. By considering this scenario, this shows that most of the respondents have food supply of less than 2 weeks. This means that if MCO continues, households from both groups need to go out to increase their food supply (Cohen 2020).

Table 1.9 Consumption of food

\begin{tabular}{|l|c|c|c|}
\hline \multirow{2}{*}{ Current food supply resistance } & Total & B40 & M40 \\
\cline { 2 - 4 } & \multicolumn{3}{|c|}{$\%$} \\
\hline Less than a week & 21.0 & 19.8 & 23.3 \\
\hline 1 to 2 weeks & 42.1 & 43.8 & 38.8 \\
\hline 2 to 3 weeks & 21.0 & 22.0 & 19.0 \\
\hline More than 4 weeks & 15.9 & 14.3 & 19.0 \\
\hline Frequency of food purchases before MCO is implemented & $\%$ & & \\
\hline Every day & 17.3 & 18.1 & 15.9 \\
\hline Once a week & 50.7 & 48.6 & 54.7 \\
\hline Once every 2 weeks & 19.3 & 19.6 & 18.6 \\
\hline Once a month & 12.7 & 13.7 & 10.9 \\
\hline Frequency of food purchases before MCO is implemented & $\%$ & & \\
\hline Every day & 8.3 & 8.1 & 8.5 \\
\hline Once a week & 61.9 & 60.7 & 64.3 \\
\hline Once every 2 weeks & 24.5 & 26.8 & 20.2 \\
\hline Once a month & 5.2 & 4.4 & 7.0 \\
\hline
\end{tabular}

The ownership of this food supply is influenced by the frequency of food purchases of respondents. The implementation of MCO will inevitably change the percentage of food purchase patterns and food stock storage. Based on the respondents' feedback, there are four patterns of food supply purchase for before and after the implementation of MCO, namely daily, once a week, every 2 weeks and once in a month. Analysis of the purchase pattern before and after MCO shows the same trend where respondents prefer to make food purchases every 2 weeks followed every day. There are individuals who make purchases once a month, but the percentage is low during MCO. This study also identified the types of spending components that influenced by income. Therefore, the determination of 
consumption factors influencing B40 and M40 income group were analyzed using multiple regression analysis.

Table 2.0 Model Summary

\begin{tabular}{|l|l|l|l|}
\hline $\mathbf{R}$ & R-square & Adjusted R Square & Std. Error of Estimate \\
\hline 0.671 & 0.721 & 0.703 & 6.592 \\
\hline
\end{tabular}

The $R$ value of 0.87 is the criterion (income) variable and is the correlation value between the predictor variable i.e. the dependent component. The value of R square R2 is 0.757 indicating that as much as 75.7 percent $(r=0.87)$ change in the criterion variable (income) is due to the change in the predictor variable i.e. dependent components (X1, X2, X3, X4, X5, X6, X7 and X8).

Table 2.1 ANOVA

\begin{tabular}{|l|l|l|l|l|l|}
\hline Model & Sum of Squares & $\mathbf{d f}$ & Mean Square & F & Sig. \\
\cline { 1 - 4 } Regression & 133.093 & 9 & 14.788 & 13.327 & 0.000 \\
\cline { 1 - 4 } Residual & 834.466 & 752 & 1.110 & & \\
\cline { 1 - 4 } & 967.559 & 761 & & & \\
\hline
\end{tabular}

Table 2.1 shows the results of Analysis of Variance (ANOVA) for the regression model which shows that significantly, eight $=$ eight independent predictor variables) is a factor influencing the income of $\mathrm{B} 40$ respondents $[(8,495)=11.751, \mathrm{P}<0.05)$

\begin{tabular}{|l|c|c|c|c|}
\hline \multirow{2}{*}{ Model } & Unstandardized Coefficients & \multirow{2}{*}{$\boldsymbol{t}$} & \multirow{2}{*}{ Sig. } \\
\cline { 2 - 5 } & $\boldsymbol{b}$ & Standard Error & & 0.000 \\
\hline Constant & 6.852 & 1.927 & 3.556 & 0.000 \\
\hline Housing loan & -0.792 & 0.126 & -6.280 & 0.005 \\
\hline Personal loan & -0.325 & 0.116 & -2.796 & 0.000 \\
\hline Vehicle loans & -0.626 & 0.119 & -5.257 & 0.078 \\
\hline Credit card payment & -0.293 & 0.166 & -1.763 & 0.549 \\
\hline Business loans & -0.156 & 0.260 & -0.600 & 0.110 \\
\hline Study loan & -0.244 & 0.153 & -2.138 & 0.033 \\
\hline Individual debt & -0.337 & 0.157 & -1.164 & 0.245 \\
\hline Rental fee & -0.281 & 0.178 & & 01 \\
\hline
\end{tabular}

${ }^{*}$ Significance level $5 \%,{ }^{*}$ Significance level $1 \%$,

Dependent variable $=$ Income, Independent variable $=$ monthly liability, $1=$ Yes $0=$ No

Based on the table, the significant results show that the multiple regression models formed by the criterion variables (dependent variables) and predictor variables can be generalized to their population. In addition, there are six standard regression coefficients of predictor variables, namely housing loan $[(b=-0.685, p<0.000)$, personal loan $(b=-0.230, p<0.010)$, vehicle loan $(b=-0.297, p<$ $0.000)$, credit card payments $(b=-0.297, p<0.010)$, individual debt $(b=-0.442, p<0.000)$ and house rental payments $(b=-0.494, p<0.000)]$.

Based on multiple regression analysis, the regression equations are as follows:

$$
\mu=4.779-0.685 X_{1}-0.230 X_{2}+0.297 X_{3}+0.225 X_{4}+0.253 X_{5}+0.124 X_{6}+0.442 X_{7}+0.494 X_{8}
$$

Since all predictor variable data is dummy variables, the value of each coefficient is in the form of a difference between having and not having dependents. For example, the remaining income difference between those who have a housing loan and those who do not have a loan is 0.685 for every RM1 of income. 
Based on the results and findings discussed in above section, there are few issues and problems that found motivating to focus on. As the COVID-19 19 is currently infecting all facets of Malaysian especially B40, it is found that spending level of B40 groups are high on payment on personal loans, housing, and car loans compared to $\mathrm{M} 40$. The result also shows that there are few of the workers who affected during the covid-19 where some of them are having unemployed, received half salary, force to take annual leave and lost their business. In terms of saving for next six months expenditure, mostly the B40 groups are having less than one month saving for next six months which is this is found as crucial. To recover back from this pandemic as they lost their income and savings, mostly the B40 groups need one month to more than six months to back as usual and due to this, the B40 groups need to take an initiative to recover their economy and support their family life compared to M40.

Instead of BPN and Moratorium, government through the Central Bank can provide emergency liquidity to the financial sector. This is to ensure that during this pandemic, financial sector have a strong back up and to avoid long term financial crisis that can affect to the economy as overall that can cause increase in unemployment rate. This policy allows the government and financial sector to focus on supporting small medium businesses (SMEs) and hard-hit industries. As the result mentioning about less savings and income by the B40 group, there are few policies that government can enforce to increase the savings of B40 group in future.

\section{Conclusion}

A scheme targeting the B40 and M40 classes is the Bantuan Prihatin Nasional (BPN) Scheme. In addition, an additional amount of USD 34.506 will be added to the People's Aid Scheme (Bantuan Sara Hidup, BSH), which since 2012 has been an annual aid scheme for groups B40 and M40 in accordance to report by Inland Revenue Board of Malaysia (2020). Nonetheless, Malaysians' monthly household poverty line income is 213.92 USD (Mokhtar et al. 2018). Therefore, in the long run, such one-off monetary assistance may not be of great benefit, especially for small-scale workers and part-time workers who have lost their source of income because of COVID-19 pandemic. Another government mitigation initiative of COVID-19 pandemic is to enable Malaysians under the age of 55 to withdraw a portion of money for 12 months (starting April 2020) from Account 2 of their Employees Provident Fund (EPF) at a maximum of 115.01 USD8 per month. However, this program is not considered inclusive since employers, self-employed and informal employees are often not included in all layers of the seafood supply chains, such as small-scale workers, part-timers and informal workers.

Moreover, emergency savings plan could be helpful for B40 group due to low monthly payment. This emergency saving plan will allows them to withdraw the money during economic downturn or during financial crisis. This is also as additional cash that they can receive other than government financial aid such as BPN. Secondly, as the commitment for housing and car loan is the highest commitment by B40 group, government are recommended to come out with special new interest rate for B40 group to reduce their monthly payment for mortgage and vehicle loan as this indirectly will reduce the commitment by the B40 group and they can have higher savings. Thirdly, government should be working with NGO's and private sector on how to build a connection between affected B40 group to have a side income business to increase their income as some of them struggling with pay cut during the pandemic crisis. Besides, in terms of labour policy, via the PRIHATIN scheme, two main programs to fight retrenchment were implemented and later upgraded by the PRIHATIN PLUS scheme, namely the Job Employment Retention Program (ERP) and Wage Subsidy Program (WSP). Both the ERP and WSP apply only to workers with monthly wages of USD 920.07.9 Under the ERP, for up to six months, employees who have decided to take a minimum of 30 days of unpaid leave or have been retrenched are entitled for financial assistance of USD 138.01 per month (Social Security Organisation Malaysia 2020).

There are few actions taken by the government to overcome the effect of this pandemic especially to the economic. The government has provided Bantuan Prihatin Nasional (BPN) that focusing to the B40 and M40 groups to reduce the burden of these groups during this pandemic and to increase 
household cashflow as some of them are being retrenched from work and loss their business. Instead of BPN, government also come out with Moratorium where all housing loans and car loan can be deferred for six months. This is also part of government initiatives to lessen the burdens to those affected and allows the borrower to have better financial plan and provide some relief to those who struggling with a liquidity crisis. The lessons of the pandemic show how inequality-ridden governments struggle to function effectively 18. The government must have a robust and inclusive stimulus plan to support the poor, not only during the pandemic, but also after, in order to cushion the effects of the Covid-19 pandemic. Hopefully, Malaysia will be compelled by this pandemic to review its social policies. If the constructive steps put in place in response to this pandemic then,-permanent changes in public health, social security and counter-cyclical measures, finance and reform, in particular could help disadvantaged groups, and overall promote sustainable development and equality.

\section{Referencias}

1. Baker, S. R., Farrokhnia, R. A., Meyer, S., Pagel, M., Yannelis, C. (2020): How does household spending respond to an epidemic? consumption during the 2020 COVID-19 pandemic.

2. Binet, M. E. (2013): The Linear Expenditure System and the Demand for Municipal Public Services: The Median Voter Specification Revisited. Urban Studies.

3. Brüggen, E. C., Hogreve, J., Holmlund, M., Kabadayi, S., Löfgren, M. (2017): Financial well-being: A conceptualization and research agenda. Journal of Business Research.

4. Cohen, M. J. (2020): Does the COVID-19 outbreak mark the onset of a sustainable consumption transition?

5. Department Of Statistics Malaysia Official Portal (no date): https://www.dosm.gov.my/v1/index.php?r=column/cone\&menu_id=d1dTROJMK2hUUUFnTnp5W UR2d3VBQT09 (17. 5. 2020).

6. Inland Revenue Board Of Malaysia, (2020). Bantuan Prihatin Nasional. Assessed On 15 April 2020. Retrieved From:[Online Resource]. Https://Bsh.Hasil.Gov.My/.

7. Ismail, M. K., Kumaran, V. V., \& Munawwarah, S. N. (2021): COVID-19 Outbreak: An Analysis of Malaysian Household Income Class During Movement Control Orders (MCO). In: Asia Proceedings of Social Sciences. 7(1), 26-29.

8. Ismail, M. K., Siwar, C., Ghazali, R., Rani, N. Z. A. A., Talib, B. A. (2019): The analysis of vulnerability faced by gahai agropolitan participants. Planning Malaysia.

9. Krejcie, R. V., Morgan, D. W. (1970): Determining Sample Size for Research Activities. Educational and Psychological Measurement.

10.Lopez-Calva, L. F., Rigolini, J., Torche, F. (2012): Is There Such a Thing as Middle Class Values?: Class Differences, Values and Political Orientations in Latin America. SSRN Electronic Journal.

11.Mokhtar, N., Dass, T. A. M., F, Sabri, M. F., S, C. (2018): A Preliminary Evaluation of Financial Literacy in Malaysia. Journal of Wealth Management \& Financial Planning, 5.

12.Mokhtar, N., Husniyah, A. R. (2017): Determinants of financial well-being among public employees in Putrajaya, Malaysia. Pertanika Journal of Social Sciences and Humanities.

13.Mokhtar, N., Husniyah, A. R., Sabri, M. F., Abu Talib, M. (2015): Financial well-being among public employees in Malaysia: A preliminary study. Asian Social Science.

14.Piaw, C. Y. (2009): Writing a series of best-selling research reference books. Journal of Scholarly Publishing.

15.Sabri, M. F., Falahati, L. (2012): Estimating a Model of Subjective Financial Well-being among College Students. International Journal of Humanities and Social Science.

16.Sabri, M. F., Zakaria, N. F. (2015): The influence of financial literacy, money attitude, financial strain and financial capability on young employees' financial well-being. Pertanika Journal of Social Sciences and Humanities.

17.Schulte, I., Heindl, P. (2017): Price and income elasticities of residential energy demand in Germany. Energy Policy.

18.Social Security Organisation Malaysia (2020): Wage Subsidy Programme, Online Resource, 
https://www.perkeso.gov.my/index.php/en/wage-subsidy-programme.

19.Song, D. L. B. (2011): Analysis and prediction for the income elasticity of the consumer demand in Chinese rural areas. In: Proceedings of 2011 IEEE International Conference on Grey Systems and Intelligent Services. IEEE, Nanjing, China.

20.Wang, C., Pan, R., Wan, X., Tan, Y., Xu, L., Ho, C. S., Ho, R. C. (2020): Immediate psychological responses and associated factors during the initial stage of the 2019 coronavirus disease (COVID19) epidemic among the general population in China. International Journal of Environmental Research and Public Health.

21.Yin-Fah, B. C., Masud, J., Hamid, T. A., Paim, L. (2010): FINANCIAL WELLBEING OF OLDER PENINSULAR MALAYSIANS: A GENDER COMPARISON. Asian Social Science.

22.Zaimah, R., Masud, J., Haron, S. A., Othman, M., Awang, A. H., Sarmila, M. D. (2013): Financial wellbeing: Financial ratio analysis of married public sector workers in Malaysia. Asian Social Science.

23.Zainudin, N., Siwar, C., Choy, E.A. \& Chamhuri, N. (2016): Low-hanging Fruits: Impact of SocioEconomic and Behavioral Characteristics on Consumers' Willingness to Pay. In: Malaysian Journal of Consumer and Family Economics. 115-126.

24.Zuriati Amani Ab Rani, N., Ghazali, R., Siwar, C., Isa, Z., Khairi Ismail, M. (2019): The Vulnerability Factor Analysis of B40 Household Income Group in Southern Region of Kelantan using Confirmatory Factor Analysis. Melaka International Conference on Social Science, Science and Technology 2019. 